\title{
EFFECT OF COVER CROPS ON SOIL ATTRIBUTES, PLANT NUTRITION, AND IRRIGATED TROPICAL RICE YIELD ${ }^{1}$
}

\author{
ANDRE FROES DE BORJA REIS ${ }^{2 *}$, RODRIGO ESTEVAM MUNHOZ DE ALMEIDA ${ }^{3}$, \\ ALOÍSIO FREITAS CHAGAS JÚNIOR ${ }^{4}$, ADRIANO STEPHAN NASCENTE ${ }^{5}$
}

\begin{abstract}
In flood plains, cover crops are able to alter soil properties and significantly affect rice nutrition and yield. The aims of this study were to determine soil properties, plant nutrition, and yield of tropical rice cultivated on flood plains after cover crop cultivation with conventional tillage (CT) and no-tillage system (NTS) at low and high nitrogen (N) fertilization levels. The experimental design was a randomized block in a split-split-plot scheme with four replications. In the main plots were cover crops [sunhemp (Crotalaria juncea and C. spectabilis), velvet bean (Mucuna aterrima), jackbean (Canavalia ensiformis), pigeon pea (Cajanus cajan), Japanese radish (Raphanus sativus), cowpea (Vigna unguiculata)] and a fallow field. In the subplots were the tillage systems (CT or NTS). The nitrogen fertilization levels in the sub-subplots were $\left(10 \mathrm{~kg} \mathrm{~N} \mathrm{ha}^{-1}\right.$ and $45 \mathrm{~kg} \mathrm{~N} \mathrm{ha}^{-1}$ ). All cover crops except Japanese radish significantly increased mineral soil nitrogen and nitrate concentrations. Sunhemp, velvet bean, and cowpea significantly increased soil ammonium content. The NTS provides higher mineral nitrogen and ammonium content than that by CT. Overall, cover crops provided higher levels of nutrients to rice plants in NTS than in CT. Cover crops provide greater yield than fallow treatments. Rice yield was higher in NTS than in CT, and greater at a higher rather than lower nitrogen fertilization level.
\end{abstract}

Keywords: Nitrogen. No-till. Tropical lowland.

\section{PLANTAS DE COBERTURA AFETANDO ATRIBUTOS DE SOLO, NUTRIÇÃO E PRODUTIVIDADE DO ARROZ IRRIGADO TROPICAL}

\begin{abstract}
RESUMO - O uso de plantas de cobertura pode alterar atributos do solo e afetar significativamente a nutrição das plantas e produtividade do arroz cultivado em planícies inundáveis. Este trabalho teve como objetivo determinar atributos do solo, nutrição de plantas e produtividade do arroz irrigado tropical em planícies irrigáveis por inundação após o cultivo de plantas de cobertura, no preparo convencional do solo (PC) ou sistema plantio direto (SPD) em baixa e alta adubação com N. O delineamento experimental foi em blocos casualizados, no esquema de parcelas sub-subdivdidas, com quatro repetições. Nas parcelas estavam as coberturas vegetais [Crotalaria juncea, C. spectabilis, mucuna preta (Mucuna aterrina), feijão de porco (Canavalia ensiformis), feijão guandu (Cajanus cajan), nabo forrageiro (Raphanus sativus), feijão caupi (Vigna unguiculata) e pousio], nas subparcelas o sistema de preparo do solo (PC ou SPD) e nas sub-subparcelas a adubação nitrogenada $\left(10\right.$ e $\left.45 \mathrm{~kg} \mathrm{ha}^{-1} \mathrm{~N}\right)$. As plantas de cobertura, com exceção do nabo forrageiro, proporcionam incrementos nos teores de $\mathrm{N}$ total e nitrato no solo. C. juncea, C. spectabilis, mucuna preta $\mathrm{e}$ feijão caupi proporcionam incrementos nos teores de amônio no solo. O SPD proporciona maiores teores de $\mathrm{N}$ total e amônio do que o PC. No âmbito geral, as plantas de cobertura proporcionaram maiores teores de nutrientes nas plantas de arroz no SPD do que no PC. As plantas de cobertura também proporcionaram maior produtividade do arroz em relação ao tratamento pousio. O rendimento do arroz é maior em SPD do que PC, e superior com alto nível de adubação nitrogenada.
\end{abstract}

Palavras Chaves: Nitrogênio. Plantio direto. Várzea tropical.

\footnotetext{
${ }^{*}$ Corresponding author

${ }^{1}$ Received for publication in $03 / 31 / 2016$; accepted in $02 / 02 / 2017$.

Paper extracted from the master thesis of the first author.

${ }^{2}$ Department of Crop Science, Escola Superior de Agricultura “Luiz de Queiróz", Piracicaba, SP, Brazil; andrefbr@usp.br.

${ }^{3}$ Embrapa Pesca e Aquicultura, Palmas, TO, Brazil; rodrigo.almeida@embrapa.br.

${ }^{4}$ Universidade Federal do Tocantins, Gurupi, TO, Brazil; chagasjraf@mail.uft.edu.br.

${ }^{5}$ Embrapa Arroz e Feijão, Santo Antônio de Goiás, GO, Brazil; adriano.nascente@embrapa.br.
} 


\section{INTRODUCTION}

Rice is a dietary staple for half of the world's population (BELLON et al., 2006; KUMAR; LADHA, 2011; NASCENTE; CRUSCIOL; COBUCCI, 2013). In Brazil, rice is cultivated in two distinct ecosystems: (a) irrigated flood plain (IFP) and (b) uplands. The area available for sustainable irrigation in Brazil is 29,564,000 ha, of which IFP constitutes $50.6 \% \quad(\sim 15,000,000$ ha) (MATTOS, 2014). It is estimated that there are about $1,000,000$ ha of tropical IFP in the Tocantins-Araguaia Valley of Brazil (COELHO et al., 2006; PELÚZIO et al., 2008; FRAGOSO et al., 2013). In this environment, hydromorphic soils with shallow subsurface horizons or temporary water table elevations predominate. These restrict water percolation are prone to accumulating excess moisture (EMBRAPA, 2013).

In the state of Tocantins, rice sown in the summer is rotated with soybean in the winter and dry seasons. The alternating use of cover crops like soybeans provides significant benefits to tropical floodplain ecosystems. According to Correia et al. (2013), the benefits of using crop rotation and succession systems in rice irrigation zones include nutrient cycling, soil use optimization, soil quality improvement by increasing organic matter, grain yield increase, and augmented crop profitability. These cultivation practices may also decrease fertilizer requirements via nutrient release from cover crop straw (VERNETTI JÚNIOR; GOMES; SCHUCH, 2009; NASCENTE et al., 2014).

Nascente and Crusciol (2015) reported that the use of cover crops contributed to the increase in soil organic matter content. Cover plants can also significantly affect soil $\mathrm{N}$ and improve the crop development environment (NASCENTE et al., 2016). The use of legumes as cover crops can provide $\mathrm{N}$ to the soil, help reduce the requirement for $\mathrm{N}$ fertilization (FAGERIA, 2014), and lower production costs (FAGERIA; STONE, 2003). There are, however, very few studies on the use of cover crops or their $\mathrm{N}$ inputs on irrigated tropical flood plains.

The hypothesis is that cover crops significantly affect soil attributes, and their impact is reflected in improved nutrition and grain yield in rice cultivated on IFP. In a no-tillage system (NTS), straw is maintained on the soil surface. It increases soil fertility and improves rice development more effectively than conventional tillage (CT) system (one plowing and two diskings). The NTS also permits the application of lower rates of $\mathrm{N}$ because it releases high levels of organic matter and nutrients to the soil. Therefore, with its reduced N inputs, NTS realizes soil attributes and grain yield comparable to those attained with the higher $\mathrm{N}$ dosages used in CT.

The objective of this study was to compare the effects of CT and NTS, and high- and low N fertilization levels on soil attributes, nutritional status, and yield of tropical rice grown following cover crops on IFP.

\section{MATERIAL AND METHODS}

The experiment was carried out in the city of Lagoa da Confusão, State of Tocantins, Brazil, at $10^{\circ} 49^{\prime} 3478^{\prime \prime} \mathrm{S}$ and $49^{\circ} 54^{\prime} 033^{\prime \prime} \mathrm{W}$, and $180 \mathrm{~m}$ altitude, in the growing season 2011/12. The climate in the region is classified as Awi (Koppen), with maximum precipitation in the summer and warm, dry winters. The soil is a Plinthaquults according to US taxonomy, and cultivated by CT for five years with an irrigated rice (summer) and soybean (winter) succession.

Prior to experimental setup, the soil was analyzed. The following results were obtained: pH $\left(\mathrm{CaCl}_{2}\right)$ : 4.9; $\mathrm{P}$ (Mehlich): $23.7 \mathrm{mg} \mathrm{dm}^{-3}$; organic matter: $54 \mathrm{~g} \mathrm{dm}{ }^{-3}$; $\mathrm{K}: 1.3 \mathrm{mmol}_{\mathrm{c}} \mathrm{dm}^{-3}$; $\mathrm{Ca}$ : $37.4 \mathrm{mmol}_{\mathrm{c}} \mathrm{dm}^{-3}$; $\mathrm{Mg}: 15.1 \mathrm{mmol} \mathrm{dm}^{-3}$; $\mathrm{Al}$ : $0 \mathrm{mmol}_{\mathrm{c}} \mathrm{dm}^{-3}$; CEC: $91 \mathrm{mmol} \mathrm{cm}{ }^{-3}$, base saturation: $59 \%$. Sand, silt and clay: $60 \%, 6 \%$, and $34 \%$, respectively.

The experimental design was a completely randomized block with spli-split-plots and four replications. The main plots had the following cover crops: Crotalaria juncea, Crotalaria spectabilis, black mucuna (Mucuna aterrima), pigeon pea (Canavalia ensiformis), guandu bean (Cajanus cajan), forage turnip (Raphanus sativus), caupi bean (Vigna unguiculata), and fallow. Either NTS or a CT was used in the subplots. Further, in the sub-subplots, the nitrogen $(\mathrm{N})$ fertilization level was either high $\left(45 \mathrm{~kg} \mathrm{ha}^{-1}\right)$ or low $\left(10 \mathrm{~kg} \mathrm{ha}^{-1}\right)$. The main plots measured $80 \mathrm{~m}^{2}$, the subplots $40 \mathrm{~m}^{2}$, and the sub-subplots $20 \mathrm{~m}^{2}$. It was considered a $3 \mathrm{~m}^{2}$ in the center of the experimental units for harvesting. The cover crops were sown to a depth of $5 \mathrm{~cm}$ using a fertilizer sowing machine (without fertilizer) on June 10, 2011, during the summer season, after rice cultivation. Twenty-five, 12, 60, 100, 30, 12, and $40 \mathrm{~kg}$ seeds ha ${ }^{-1}$ of Crotalaria juncea, C. spectabilis, black mucuna, pigeon pea, guandu bean, forage turnip, and caupi beans were sown respectively. All seeds were planted $45 \mathrm{~cm}$ apart in rows except for forage turnip seeds, which were sown used $17-\mathrm{cm}$ rows. All plants were irrigated by sub-irrigation. After 135 days, the average total dry matter (root + shoot) was $3567 \mathrm{~kg} \mathrm{ha}^{-1}$ for $C$. juncea, $4565 \mathrm{~kg} \mathrm{ha}^{-1}$ for C. spectabilis, $1848 \mathrm{~kg} \mathrm{ha}^{-1}$ for black mucuna, $2298 \mathrm{~kg} \mathrm{ha}^{-1}$ for pigeon pea, $2944 \mathrm{~kg} \mathrm{ha}^{-1}$ for guandu bean, $1897 \mathrm{~kg} \mathrm{ha}^{-1}$ for forage turnip, and $2322 \mathrm{~kg} \mathrm{ha}^{-1}$ for cowpea.

Eleven days before rice sowing, each plot was divided into two subplots according to soil management type (CT or NTS). In the CT plot, a leveling grid with 22 " disks was used to incorporate the organic residues down to a depth of $\leq 10 \mathrm{~cm}$. For the NTS plot, plants were desiccated with glyphosate 
at $960 \mathrm{~g}$ a.i. $\mathrm{ha}^{-1}$ and 2,4-D at $640 \mathrm{~g}$ a.i. $\mathrm{ha}^{-1}$.

The subplots were themselves divided into sub-subplots partitioned into low $\mathrm{N}\left(10 \mathrm{~kg} \mathrm{ha}{ }^{-1}\right.$ applied at sowing), and high $\mathrm{N}$ (45 kg ha' $\mathrm{kg}^{-1}$ tol: $10 \mathrm{~kg} \mathrm{ha}^{-1}$ applied at sowing, and $30 \mathrm{~kg} \mathrm{ha}^{-1}$ applied as topdressing $25 \mathrm{~d}$ after rice emergence). The nitrogen source was urea.

The rice crop was planted on December 3, 2011 , by using a no-tillage seeder machine, with a distance of $0.17 \mathrm{~m}$ between rows. The cultivar used was IRGA 424, a variety commonly used by local growers. It has a life cycle of $\sim 117 \mathrm{~d}$ and was sown at a seed density of $85 \mathrm{~kg} \mathrm{ha}^{-1}$. Sowing fertilization was performed according to crop needs and soil analysis, as recommended by Fageria (2006). A total of $90 \mathrm{~kg} \mathrm{ha}{ }^{-1} \mathrm{P}_{2} \mathrm{O}_{5}$ (triple superphosphate) was applied to the sowing row. A total of $70 \mathrm{~kg} \mathrm{ha}^{-1} \mathrm{~K}_{2} \mathrm{O}$ (potassium chloride) was used. One-third of it was applied in the sowing row and the remainder $40 \mathrm{~d}$ after sowing.

After $10 \mathrm{~d}$ soil management and the day before rice sowing, soil samples were drawn for nitrogen analysis. In each sub-subplot, eight separate samples were collected with a Dutch augur at a depth range of $0-10 \mathrm{~cm}$ and pooled to form one composite sample. The samples were immediately frozen. Total nitrogen, ammonium, and nitrate were measured. The total nitrogen was determined by the Kjeldahl method. $\mathrm{N}_{-} \mathrm{NO}_{3}{ }^{-}$and $\mathrm{N}-\mathrm{NH}_{4}{ }^{+}$were determined by colorimetry (MONIZ; JORGE; VALADARES, 2009).

At $80 \mathrm{~d}$ after rice emergence, leaf samples were collected at the full flowering stage to determine leaf nutrient content. Each sample consisted of fifty flag leaves per sub-subplot. The material was oven dried at $65^{\circ} \mathrm{C}$ for $72 \mathrm{~h}$, ground, and submitted for laboratory analysis. The material was digested with nitroperchloric acid. Phosphorus was determined by colorimetry, calcium and magnesium by atomic absorption spectrophotometry, potassium by flame emission photometry, and sulfur by turbidimetry (MONIZ; JORGE; VALADARES, 2009).

At $115 \mathrm{~d}$ after sowing, when the rice was physiologically mature, biometric parameters were determined. Plant height $(\mathrm{m})$ between the soil surface and the upper end of the highest panicle was measured for ten plants selected at random. The number of tillers per plant was determined for all the plants on $1 \mathrm{~m}$ of row. The number of panicles per $\mathrm{m}^{2}$ was determined by counting the number of panicles in the central $3 \mathrm{~m}^{2}$ area of each sub-subplot. Grain yield was determined by weighing the grains harvested from each sub-subplots, correcting the moisture content to $13 \%$, and converting to the weight to $\mathrm{kg} \mathrm{ha}^{-1}$.

All data were subjected to ANOVA by the F-test using ASSISTAT software, v. 7.6 beta (SILVA; AZEVEDO, 2009). Means were subjected to the Scott-Knot test at 5\% probability.

\section{RESULTS AND DISCUSSION}

\section{Mineral forms of $N$ in the soil}

There was no interaction between cover crop and soil management type for total $\mathrm{N}$, ammonium, and nitrate (Table 1). The average total $\mathrm{N}$ for all legume species was $4250 \mathrm{mg} \mathrm{kg}^{-1}, 42.5 \%$ higher than the control (fallow). Forage turnip had the same total $\mathrm{N}$ content as the fallow control.

Table 1. Nitrogen content (total $\mathrm{N})$, ammoniacal nitrogen $\left(\mathrm{N} \mathrm{NH}_{4}^{+}\right)$, and nitrate nitrogen $\left(\mathrm{N} \mathrm{NO}_{3}^{-}\right)$in the soil as functions of cover crop and soil management.

\begin{tabular}{lccc}
\hline \multirow{2}{*}{ Cover crop } & Total N & $\mathrm{N} \mathrm{NH}_{4}^{+}$ & $\mathrm{N} \mathrm{NO}_{3}{ }^{-}$ \\
\cline { 2 - 3 } & & ------ & $16.0 \mathrm{a}$ \\
\hline Crotalaria juncea & $4535 \mathrm{a}^{+}$ & $32.5 \mathrm{a}$ & $15.6 \mathrm{a}$ \\
Crotalaria spectabilis & $4446 \mathrm{a}$ & $30.8 \mathrm{a}$ & $15.3 \mathrm{a}$ \\
Black mucuna & $4522 \mathrm{a}$ & $31.2 \mathrm{a}$ & $13.5 \mathrm{a}$ \\
Pigeon pea & $3927 \mathrm{a}$ & $27.2 \mathrm{~b}$ & $13.0 \mathrm{a}$ \\
Guandu bean & $3820 \mathrm{a}$ & $26.0 \mathrm{~b}$ & $14.8 \mathrm{a}$ \\
Cowpea & $4156 \mathrm{a}$ & $29.8 \mathrm{a}$ & $10.6 \mathrm{~b}$ \\
Forage turnip & $2944 \mathrm{~b}$ & $23.2 \mathrm{~b}$ & $9.6 \mathrm{~b}$ \\
Fallow & $2983 \mathrm{~b}$ & $20.5 \mathrm{~b}$ & $14.12 \mathrm{a}$ \\
\hline \multicolumn{1}{c}{ Soil management } & & $29.29 \mathrm{a}$ & $13.01 \mathrm{a}$ \\
\hline No-tillage system & $4123 \mathrm{a}$ & $26.00 \mathrm{~b}$ & \\
Conventional tillage & $3710 \mathrm{~b}$ &
\end{tabular}

${ }^{+}$Means followed by the same letter in the column do not significantly differ from each other according to the Scott-Knott test $(p<0.05){ }^{*}, * *$, and ns: significant $(p<0.05),(p<0.01)$, and not significant for the F-test, respectively.

Biological $\mathrm{N}$ fixation by bacteria symbiotic with the legumes probably increased soil $\mathrm{N}$ (FAGERIA; SANTOS, 2007; FAGERIA, 2014; NASCENTE et al., 2016). Nitrogen is made available in the soil from the mineralization of organic matter by soil microbes. They convert organic $\mathrm{N}$ to ammonium ion $\left(\mathrm{NH}_{4}{ }^{+}\right)$and oxidize the latter to nitrate $\left(\mathrm{NO}_{3}{ }^{-}\right)$(MARY et al., 1996). It is 
known that legumes increase soil $\mathrm{N}$ levels in other conditions as well. Legumes also increase total $\mathrm{N}$ more than those of the mineral (ammoniacal and nitric) forms. Mclaren and Cameron (1996) and Fageria, Santos and Oliveira (2013) report that more than $94 \%$ of the soil $\mathrm{N}$ is bound in plant residue, microbial mass, and humus.

The ammoniacal $\mathrm{N}$ content in the soil was equivalent in crotalaria, black mucuna, and cowpea (32.5 mg kg-1, $30.8 \mathrm{mg} \mathrm{kg} \mathrm{mg}^{-1}$, and $31.2 \mathrm{mg} \mathrm{kg}$, respectively; Table 1). The ammoniacal $\mathrm{N}$ content in the soil under pigeon pea, guandu bean, forage turnip, and fallow were, on average, $30 \%$ less than the above. Both nitric- and total $\mathrm{N}$ values were the highest where legumes were grown, but were $45 \%$ lower than these in the soil under forage turnip and fallow.

For all treatments, soil ammonium levels were higher than those of nitrate (Table 1). This observation can be explained by the fact that Nitrosomonas spp. and Nitrobacter spp., which oxidize ammonia to nitrite and then nitrite to nitrate, flourish when soil $\mathrm{pH}$ is corrected and soil is aerated (POUDEL; HORWATH; LANINI, 2002). Soils with $\mathrm{pH}<5.0$, such as those in the experimental area, transform ammonium to nitrate more slowly than that by highly alkaline soils (SILVA; VALE; GUILHERME 1994).

Soil management influenced the levels of total $\mathrm{N}$ and ammoniacal $\mathrm{N}$ in 10 and $11 \%$, respectively, but was not significant for the nitrate content (Table 1). The incorporation of residues into conventionally prepared soil greatly accelerates organic matter decomposition (THONNISSEN et al., 2000). Most of the $\mathrm{N}$ is released at the start of decomposition and coincides with low crop $\mathrm{N}$ demand during the early stages of plant development. If mineral $\mathrm{N}$ is available early, some of it may be lost to $\mathrm{NO}_{3}{ }^{-}$leaching (ROSECRANCE et al., 2000). As this present study demonstrated, in the NTS, where plant residues are left on the soil surface and are not incorporated into it, both the soil organic matter and total $\mathrm{N}$ content are significantly higher than those of the CT system. Ammonium is the first compound produced by bacteria that transform organic matter (FAGERIA, 2014) and $\mathrm{pH}<5$ is not conducive to the conversion of ammonium into nitrate. Therefore, as the present study indicated, it was more probable to detect higher values of ammonium in the NTS than the CTS.

\section{Rice plant nutrient content}

Leaf nutrient content analysis revealed a triple interaction among the factors for $\mathrm{N}$ content (Table 2). Phosphorus was significantly affected by soil management type, and there was an interaction between cover crops and nitrogen fertilization level (Table 3). Potassium was significantly affected by both cover crop and soil management type, and there was no interaction (Table 4). Neither calcium nor magnesium was affected by the factors evaluated. Sulfur was significantly affected by both cover crop type and nitrogen fertilization level (Table 4).

Table 2. Triple interaction (cover crops, soil management type, and nitrogen fertilization level) with leaf nitrogen content.

\begin{tabular}{|c|c|c|}
\hline \multicolumn{3}{|c|}{ Low $\mathrm{N}\left(10 \mathrm{~kg} \mathrm{ha}^{-1}\right)$} \\
\hline \multirow{3}{*}{ Cover crop } & \multicolumn{2}{|c|}{ Soil management } \\
\hline & No-tillage system & Conventional tillage \\
\hline & \multicolumn{2}{|c|}{ 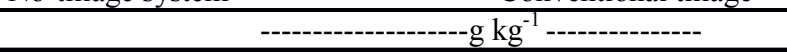 } \\
\hline Crotalaria juncea & $20.23 \mathrm{aA} *$ & $15.93 \mathrm{bB}$ \\
\hline Crotalaria spectabilis & $18.24 \mathrm{bA}$ & $15.23 \mathrm{bB}$ \\
\hline Black mucuna & $17.90 \mathrm{bA}$ & $17.43 \mathrm{aA}$ \\
\hline Pigeon pea & $16.56 \mathrm{cA}$ & $14.91 \mathrm{cB}$ \\
\hline Guandu bean & $19.77 \mathrm{bA}$ & $15.76 \mathrm{bB}$ \\
\hline Cowpea & $15.33 \mathrm{cA}$ & $16.32 \mathrm{bB}$ \\
\hline Forage turnip & $14.53 \mathrm{dA}$ & $15.33 \mathrm{bA}$ \\
\hline \multirow[t]{3}{*}{ Fallow } & $14.70 \mathrm{dA}$ & $14.17 \mathrm{cA}$ \\
\hline & \multicolumn{2}{|c|}{ High N $\left(45 \mathrm{~kg} \mathrm{ha}^{-1}\right)$} \\
\hline & \multicolumn{2}{|c|}{ Soil management } \\
\hline \multirow[t]{2}{*}{ Cover crop } & No-tillage system & No-tillage system \\
\hline & \multicolumn{2}{|c|}{ - } \\
\hline Crotalaria juncea & $17.37 \mathrm{cA}$ & $16.84 \mathrm{bA}$ \\
\hline Crotalaria spectabilis & $25.15 \mathrm{aA}$ & $23.05 \mathrm{aB}$ \\
\hline Black mucuna & $23.33 \mathrm{aA}$ & $18.81 \mathrm{bB}$ \\
\hline Pigeon pea & $18.92 \mathrm{bA}$ & $18.84 \mathrm{bA}$ \\
\hline Guandu bean & $23.34 \mathrm{aA}$ & $16.60 \mathrm{bB}$ \\
\hline Cowpea & $17.15 \mathrm{cA}$ & $16.14 \mathrm{bA}$ \\
\hline Forage turnip & 20.18 bA & $15.65 \mathrm{cB}$ \\
\hline Fallow & $15.97 \mathrm{eA}$ & $14.33 \mathrm{cA}$ \\
\hline
\end{tabular}

*Means followed by the same letter, whether lowercase in columns or upper case in rows, do not differ significantly according to the Scott-Knott test at $0.01 \leq p<0.05$. 
A. F. B. REIS et al.

Table 3. Double interaction (cover crops and nitrogen fertilization levels) and isolated effect of soil management on leaf phosphorus content.

\begin{tabular}{lcc}
\hline & \multicolumn{2}{c}{ Level of N fertilization } \\
\cline { 2 - 3 } \multicolumn{1}{c}{ Cover crop } & Low Nitrogen & High Nitrogen \\
\cline { 2 - 3 } & \multicolumn{1}{c}{$1.06 \mathrm{aA}^{*}$} & $0.98 \mathrm{bA}$ \\
\hline Crotalaria juncea & $1.08 \mathrm{aA}$ & $1.23 \mathrm{aA}$ \\
Crotalaria spectabilis & $1.02 \mathrm{aB}$ & $1.23 \mathrm{aA}$ \\
Black mucuna & $0.81 \mathrm{bB}$ & $1.12 \mathrm{aA}$ \\
Pigeon pea & $1.01 \mathrm{aB}$ & $1.18 \mathrm{aA}$ \\
Guandu bean & $0.87 \mathrm{bB}$ & $1.13 \mathrm{aA}$ \\
Cowpea & $0.88 \mathrm{bB}$ & $1.07 \mathrm{bA}$ \\
Forage turnip & $0.85 \mathrm{bA}$ & $0.99 \mathrm{bA}$ \\
Fallow & & Phosphorus Content \\
\hline \multicolumn{1}{c}{ Soil management } & & $0.987 \mathrm{~b}$ \\
\hline Conventional tillage & & $1.071 \mathrm{a}$ \\
No-tillage system & & \\
\hline
\end{tabular}

*Means followed by the same letter, whether lowercase in columns or upper case in rows, do not differ significantly according to the Scott-Knott test at $0.01 \leq p<0.05$.

Table 4. Rice leaf $\mathrm{K}$ and $\mathrm{S}$ content as functions of cover crop, soil management type, and nitrogen fertilization level.

\begin{tabular}{|c|c|c|}
\hline \multirow{2}{*}{ Cover crop } & Potassium content & Sulfur content \\
\hline & \multicolumn{2}{|c|}{ - } \\
\hline Crotalaria juncea & $8.16 \mathrm{a}^{*}$ & $0.61 \mathrm{a}$ \\
\hline Crotalaria spectabilis & $9.03 \mathrm{a}$ & $0.68 \mathrm{a}$ \\
\hline Black mucuna & $8.28 \mathrm{a}$ & $0.53 \mathrm{~b}$ \\
\hline Pigeon pea & $8.05 \mathrm{a}$ & $0.52 \mathrm{~b}$ \\
\hline Guandu bean & $7.79 \mathrm{a}$ & $0.54 \mathrm{~b}$ \\
\hline Cowpea & $6.87 \mathrm{a}$ & $0.64 \mathrm{a}$ \\
\hline Forage turnip & $7.65 \mathrm{a}$ & $0.60 \mathrm{a}$ \\
\hline Fallow & $8.22 \mathrm{a}$ & $0.45 \mathrm{~b}$ \\
\hline \multirow{2}{*}{ Soil management } & \multicolumn{2}{|c|}{ Potassium content } \\
\hline & \multicolumn{2}{|c|}{---------------g kg ${ }^{-1}$------------- } \\
\hline Conventional tillage & \multicolumn{2}{|c|}{$7.49 \mathrm{~b}$} \\
\hline No-tillage system & \multicolumn{2}{|c|}{$8.42 \mathrm{a}$} \\
\hline \multirow{2}{*}{ Level of nitrogen fertilization } & \multicolumn{2}{|c|}{ Sulfur content } \\
\hline & \multicolumn{2}{|c|}{ 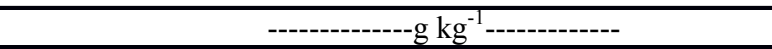 } \\
\hline Low $\left(10 \mathrm{~kg} \mathrm{ha}^{-1} \mathrm{~N}\right)$ & \multicolumn{2}{|c|}{$0.534 \mathrm{a}$} \\
\hline $\operatorname{High}\left(45 \mathrm{~kg} \mathrm{ha}^{-1} \mathrm{~N}\right)$ & \multicolumn{2}{|c|}{$0.615 \mathrm{~b}$} \\
\hline
\end{tabular}

*Means followed by the same letter do not differ significantly according to the Scott-Knott test at $0.01 \leq p<0.05$.

Rice leaf nitrogen levels were the highest in treatments with low nitrogen fertilization $\left(10 \mathrm{~kg} \mathrm{ha}^{-1}\right.$ of $\left.\mathrm{N}\right)$ for all cover crop types in the NTS (Table 2). Black mucuna, forage turnip, and fallow provided similar levels of $\mathrm{N}$ in both soil management systems. In the NTS, leaf N levels were higher at the highest nitrogen fertilization levels, but $C$. spectabilis, black mucuna, pigeon pea, and forage turnip provided similar leaf $\mathrm{N}$ levels in both systems. As shown in Table 1, the NTS produces greater accumulations of organic matter and mineral $\mathrm{N}$ in the soil than does the CTS. Therefore, at these higher soil $\mathrm{N}$ levels, the rice plants were able to absorb more of the nutrient than those under the CTS at comparable soil $\mathrm{N}$ levels.

At low nitrogen fertilization levels, the 
highest $\mathrm{N}$ content was found where $C$. juncea grew under the NTS and black mucuna grew under the CT (Table 2). When a higher amount of $\mathrm{N}$ was added to the soil, the highest levels of $\mathrm{N}$ were obtained with C. spectabilis, black mucuna, and pigeon pea under NTS, and with $C$. spectabilis under CT. At both nitrogen fertilization levels and both soil management types, the fallow (control) treatment provided the lowest $\mathrm{N}$ levels to the rice plants. Therefore, the use of cover crops efficiently increases $\mathrm{N}$ levels in rice plants.

Although it is not a legume, forage turnip provided higher $\mathrm{N}$ content for cultivated rice than did fallow in both soil management types and at all $\mathrm{N}$ fertilization levels (Table 2). Despite the fact that the forage turnip did not add $\mathrm{N}$ to the soil, it can cycle soil mineral $\mathrm{N}$ mineral and reduce leaching (AITA et al., 2004).

$\mathrm{P}$ levels in the rice plants were higher in all cases of cover crops at the highest level of $\mathrm{N}$, differing from black mucuna, pigeon pea, guandu bean, cowpea and forage turnip (Table 3 ). In general, cover crops that produced lower leaf $\mathrm{N}$ contents (Table 2) also produced lower leaf $\mathrm{P}$ contents. Therefore, there is a correlation between $\mathrm{N}$ and $\mathrm{P}$ uptake in rice plants. The correlation analysis between these two nutrients was highly significant and positive $(\mathrm{r}=0.7515, p<0.001)$. According to Fageria (2014), N and P are components in several plant structures, and increasing the levels of one nutrient generally implies that the other increases as well. In the NTS, the leaf P content was higher than that in CT. The NTS soil also had higher values of total $\mathrm{N}$ and ammonium than those in $\mathrm{CT}$ soil. Thus, higher plant $\mathrm{N}$ levels also require higher $\mathrm{P}$ levels.

Cover crops did not affect rice $\mathrm{K}$ content (Table 4). After cover crop management and the onset of straw degradation, $\mathrm{K}$ leached into the soil because this nutrient does not constitute any part of the plant structure. In fact, $\mathrm{K}$ is the nutrient most readily released to the soil (FAGERIA; SANTOS, 2007). Potassium is highly mobile at all concentrations in all plant cells and tissues (CALONEGO; FOLONI; ROSOLEM, 2005). Rosolem, Calonego and Foloni (2003) subjected the residues of six cover crop species to various amounts of rainfall and observed considerable leaching of $\mathrm{K}$, with values ranging from $7-24 \mathrm{~kg} \mathrm{ha}$. Soil K leaches readily (CALONEGO; FOLONI; ROSOLEM, 2005). It is, therefore, likely that nutrients were released from the cover crop straws and some of the $\mathrm{K}$ leached. For this reason, there were no significant differences among the treatments in terms of rice leaf $\mathrm{K}$ content. In fact, the $\mathrm{K}$ values were higher in plants grown under NTS than in those grown under CT. CT promotes $\mathrm{K}$ leaching because, unlike NTS, this soil management involves plowing and residue degradation.

The sulfur content was higher in $C$. spectabilis, which did not differ from the cowpea, $C$. juncea and forage turnip (Table 4). C. spectabilis, $C$. juncea, and cowpea provided the greatest increase in total soil $\mathrm{N}$ and ammonium content. Sulfur forms an integral part of the plant structure, because it is a constituent of cystine, cysteine, and methionine. These amino acids account for $\sim 90 \%$ of the total plant S. Sulfur also participates in plant enzymatic processes and redox reactions (MALAVOLTA; VITTI; OLIVEIRA, 1997). Therefore, there probably is a relationship between nitrogen and sulfur in plants. In the present study, a strong correlation was found between the levels of $\mathrm{N}$ and $\mathrm{S}$ in the soil $(\mathrm{r}=0.274, p<0.001)$ and the plant $(\mathrm{r}=0.4792, p<0.001)$.

Diagnosis and Recommendation Integrated System (DRIS) analysis on rice cultivated on IFP indicates that the nutrient balance in rice leaf is $26 \mathrm{~g} \mathrm{~kg}^{-1} \mathrm{~N}, 2.0 \mathrm{~g} \mathrm{~kg}^{-1} \mathrm{P}, 12.5 \mathrm{~g} \mathrm{~kg}^{-1} \mathrm{~K}, 2.9 \mathrm{~g} \mathrm{~kg}^{-1} \mathrm{Ca}$, $1.5 \mathrm{~g} \mathrm{~kg}^{-1} \mathrm{Mg}$, and $1.8 \mathrm{~g} \mathrm{~kg}^{-1} \mathrm{~S}$ (GUINDANI; ANGHINONI; NACHTIGALL, 2009). Thus, in the present study, only the $\mathrm{Ca}$ and $\mathrm{Mg}$ levels were optimal for crop development, and that even the cover crops did not suffice to supply the needs of the rice. Therefore, supplementary fertilizer application is required (MALAVOLTA, 1980).

\section{Morphologic parameters}

Cover crops affected all morphological parameters (plant height, tillering, panicle mass, and grain yield) (Table 5). Soil management affected panicle mass and grain yield. Nitrogen fertilization levels affected tillering, panicle mass, and grain yield. There was an interaction between soil management and nitrogen fertilization level for plant height.

When rice was cultivated after $C$. spectabilis, pigeon pea, $C$. juncea, cowpea, and black mucuna, its yield was $\sim 7 \%$ greater than that obtained for rice sown after fallow (Table 5). Rice sown after pigeon pea and forage turnip produced plants that were $4.5 \%$ and $6 \%$ shorter than the plants that grew after $C$. spectabilis cultivation, respectively. The rice that was planted and grew after fallow had about the same height as the plants that grew after pigeon pea and forage turnip cultivation. Cazetta et al. (2008) reported a relative rice height increase following the planting of black mucuna, $C$. juncea, and pigeon pea. This difference may be explained by the fact that the cover crops increased nitrogen availability (ARF et al., 2015a). At low $\mathrm{N}$ fertilization levels, rice plants in the NTS were $6.6 \%$ taller than those in CT. N directly affects plant height, and more $\mathrm{N}$ was available in the NTS than in the CT. On the other hand, despite the greater availability of this nutrient, no differences between treatments were observed. The high-N treatment produced plants that were $8.6 \%$ higher than those from the low-N treatment under CT, but the plants had the same height at both $\mathrm{N}$ levels under the NTS. 
A. F. B. REIS et al.

Table 5. Morphological parameters and grain yield in irrigated rice crop as functions of cover crop type, soil management type, nitrogen fertilization level, and double interaction (soil management and nitrogen fertilization level) for plant height.

\begin{tabular}{|c|c|c|c|c|}
\hline \multirow{2}{*}{ Cover crop } & Plant height & Tillers & Panicle mass & Grain yield \\
\hline & ----- cm ----- & No. tillers & ----- g ----- & $-\mathrm{kg} \mathrm{ha}^{-1}$ \\
\hline Crotalaria juncea & $64.25 \mathrm{a}^{*}$ & $4.9 \mathrm{a}$ & $190 \mathrm{a}$ & $7397 \mathrm{a}$ \\
\hline Crotalaria spectabilis & $65.37 \mathrm{a}$ & $5.2 \mathrm{a}$ & $190 \mathrm{a}$ & $7381 \mathrm{a}$ \\
\hline Black mucuna & $63.00 \mathrm{a}$ & $4.2 \mathrm{c}$ & $184 \mathrm{a}$ & $7167 \mathrm{a}$ \\
\hline Pigeon pea & $61.00 \mathrm{~b}$ & $3.9 \mathrm{c}$ & $183 \mathrm{a}$ & $6898 \mathrm{a}$ \\
\hline Guandu bean & $64.81 \mathrm{a}$ & $4.2 \mathrm{c}$ & $177 \mathrm{a}$ & $7137 \mathrm{a}$ \\
\hline Cowpea & $63.37 \mathrm{a}$ & $5.0 \mathrm{a}$ & $192 \mathrm{a}$ & $7476 \mathrm{a}$ \\
\hline Forage turnip & $62.56 \mathrm{~b}$ & $4.6 \mathrm{~b}$ & $169 \mathrm{a}$ & $5654 \mathrm{~b}$ \\
\hline Fallow & $60.87 \mathrm{~b}$ & $3.3 \mathrm{~d}$ & $145 \mathrm{~b}$ & $6559 \mathrm{~b}$ \\
\hline \multirow{2}{*}{ Soil management } & \multicolumn{2}{|c|}{ Tillers } & Panicle mass & Grain yield \\
\hline & \multicolumn{2}{|c|}{ No. tillers } & ----- g ----- & $-\mathrm{kg} \mathrm{ha}^{-1}-$ \\
\hline No-tillage system & \multicolumn{2}{|c|}{4.34} & $192 \mathrm{a}$ & $7457 \mathrm{a}$ \\
\hline Conventional tillage & \multicolumn{2}{|c|}{4.53} & $166 \mathrm{~b}$ & $6461 \mathrm{~b}$ \\
\hline \multirow{2}{*}{$\mathrm{N}$ fertilization level } & \multicolumn{2}{|c|}{ Tillers } & Panicle mass & Grain yield \\
\hline & \multicolumn{2}{|c|}{ No. tillers } & ----- g ----- & $-\mathrm{kg} \mathrm{ha}^{-1}-$ \\
\hline High $N$ & \multicolumn{2}{|c|}{$4.92 \mathrm{a}$} & $188 \mathrm{a}$ & 7299 a \\
\hline \multirow[t]{2}{*}{ Low N } & \multicolumn{2}{|c|}{$3.95 \mathrm{~b}$} & $170 \mathrm{~b}$ & $6618 b$ \\
\hline & \multicolumn{4}{|c|}{ Plant height } \\
\hline \multirow{2}{*}{ Soil management } & \multicolumn{3}{|c|}{ Low $\mathrm{N}$} & High $N$ \\
\hline & \multicolumn{4}{|c|}{ - } \\
\hline Conventional system & \multicolumn{3}{|c|}{$59.5 \mathrm{bB}$} & $65.1 \mathrm{aA}$ \\
\hline No-tillage system & & $63.7 \mathrm{aA}$ & & $64.1 \mathrm{aA}$ \\
\hline
\end{tabular}

*Means followed by the same letter do not differ significantly according to the Scott-Knott test at $0.01 \leq p<0.05$.

The highest numbers of tillers were observed in the rice sown after $C$. juncea, cowpea, and $C$. spectabilis (Table 5). The fallow treatment resulted in rice plants with the lowest numbers of tillers. In the absence of environmental stress, tillering is a very important component of rice yield (ARF et al., 2015a) and is a function of $\mathrm{N}$ availability (FAGERIA; BALIGAR, 2005; ARF et al., 2015b). The correlation between rice leaf $\mathrm{N}$ content and tillering was significant and positive $(\mathrm{r}=0.409$, $p<0.001)$. Higher tillering was observed in rice plants cultivated with high nitrogen fertilization levels than those treated with low amounts of N. The soil management type did not affect this variable.

Panicle mass was also influenced by cover crop type (Table 5). Rice cultivation after fallow produced the lowest panicle mass and differed significantly from the other treatments. Panicle production per unit area is the main rice production measure, and it is significantly affected by nitrogen fertilization levels (FAGERIA; STONE, 2003; ARF et al., 2015a). In this study, the correlation between panicle mass and grain yield was significant $(\mathrm{r}=0.281, p<0.05)$. Both NTS (higher N content; Table 1) and high $\mathrm{N}$ fertilization levels produced higher panicle mass values.

Grain yields derived from cowpea $\left(7,476 \mathrm{~kg} \mathrm{ha}^{-1}\right)$, C. juncea $\left(7,397 \mathrm{~kg} \mathrm{ha}^{-1}\right), C$. spectabilis $\left(7,381 \quad \mathrm{~kg} \mathrm{ha}^{-1}\right)$, black mucuna $\left(7,167 \mathrm{~kg} \mathrm{ha}^{-1}\right)$, guandu bean $\left(7,137 \mathrm{~kg} \mathrm{ha}^{-1}\right)$, and pigeon pea $\left(6,898 \mathrm{~kg} \mathrm{ha}^{-1}\right)$ were all similar and did not significantly differ from each other (Table 5). Fallow treatment $\left(6,559 \mathrm{~kg} \mathrm{ha}^{-1}\right)$ and forage turnip $\left(5,654 \mathrm{~kg} \mathrm{ha}^{-1}\right)$ resulted in lower rice yields and differed significantly from the other treatments. Nascente, Crusciol and Cobucci (2013) used grasses as cover crops for upland rice. They reported that millet gave rise to the highest grain yield. Fageria and Santos (2007) observed that planting the cover crop gray mucuna (Mucuna cinereum) and mineral fertilization prior to irrigated rice cultivation (in the same conditions as IFP) significantly increased grain yield.

The highest grain yield was obtained under 
NTS and at the higher $\mathrm{N}$ fertilization level (Table 5). According to Fageria and Santos (2007), nitrogen is the major nutrient responsible for significant rice yield increases. In this study, NTS resulted in better performance of morphological parameters and higher productivity than did CT. This observation does not corroborate the report of Kluthcouski et al. (2000), who found lower productivity of upland rice under NTS than CT and proposed that the crop was not adapted to the NTS. Nevertheless, flooding can alter the response of rice to the NTS since the water and anaerobic conditions change soil structure and permeability (FAGERIA; SANTOS, 2003).

Based on the data obtained in this study, the use of cover crops can increase soil $\mathrm{N}$, improve plant nutrition, and augment rice yield on tropical flood plains. Cover crops significantly improve both soil- and crop quality compared with the fallow treatment.

\section{CONCLUSIONS}

Except for forage turnip, all cover crops provided significant increases in total soil $\mathrm{N}$ and nitrate content;

Crotalaria juncea, C. spectabilis, black mucuna, and cowpea provided significant increases in soil ammonium content;

The no-tillage system provided higher total soil $\mathrm{N}$ and ammonium levels than that by conventional tillage;

In general, cover crops provided higher nutrient levels to rice plants under no-tillage systems than conventional tillage;

Cover crops provided higher rice yield than the fallow treatment. Rice grain yield is higher under no-tillage systems than conventional tillage, and at higher $\mathrm{N}$ fertilization levels.

\section{REFERENCES}

AITA, C. et al. Consorciação de plantas de cobertura antecedendo o milho em plantio direto. I-Dinâmica do nitrogênio no solo. Revista Brasileira de Ciência do Solo, Viçosa, v. 28, n. 4, p. 739-749, 2004.

ARF, O. et al. Adubação antecipada de nitrogênio na cultura do arroz de terras altas sob plantio direto. Revista de Ciências Agrárias, Belém, v. 58, n. 1, p. 6-13, 2015a.

ARF, O. et al. Espaçamento e adubação nitrogenada afetando o desenvolvimento do arroz de terras altas sob plantio direto. Revista Ceres, Viçosa, v. 62, n. 5, p. 475-482, 2015b.

BELLON, M. R. et al. IRRI's upland rice research: follow-up review to the 6th IRRI EPMR. 1. ed. Roma, Italy: CGIAR, 2006. 36 p.

CALONEGO, J. C.; FOLONI, J. S. S.; ROSOLEM, C. A. Lixiviação de potássio da palha de plantas de cobertura em diferentes estádios de senescência após a dessecação química. Revista Brasileira de Ciência do Solo, Viçosa, v. 29, n. 1, p. 99-108, 2005

CAZETTA, D. A. et al. Desempenho do arroz de terras altas com a aplicação de doses de nitrogênio e em sucessão às culturas de cobertura do solo em sistema de plantio direto. Bragantia, Campinas, v. 67 , n. 2, p. 471-479, 2008

COELHO, M. R. et al. Solos. In: SANTOS, A. B.; STONE, L. F.; VIERA, N. R. A. (Eds.). A Cultura do Arroz no Brasil. Santo Antônio de Goiás: Embrapa. 2006, cap. 3, p. 161-208.

CORREIA, S. L. et al. Estratégias de manejo da palha de azevém para cultivo do arroz irrigado em sucessão. Revista Brasileira de Ciência do Solo, Viçosa, v. 37, n. 2, p. 512-520, 2013.

EMPRESA BRASILEIRA DE PESQUISA AGROPECUÁRIA - EMBRAPA. Sistema brasileiro de classificação de solos. 3 . ed. Brasília, DF: Embrapa, 2013. 353 p.

FAGERIA, N. K. Adubação e Calagem. In: SANTOS, A. B.; STONE, L. F.; VIERA, N. R. A. (Eds.). A Cultura do Arroz no Brasil. Santo Antônio de Goiás: Embrapa. 2006, cap. 6, p. 425-450.

FAGERIA, N. K. Mineral nutrition of rice. 1. ed. Boca Raton, USA: CRC Press, 2014. 552 p.

FAGERIA, N. K.; BALIGAR, V. C. Role of cover crops in improving soil and row crop productivity. Communications in Soil Science and Plant Analysis, Philadelphia, v. 36, n. 19-20, p. 2733-2757, 2005.

FAGERIA, N. K.; SANTOS, A. B. Classificação e atributos físicos e químicos dos solos de várzea. In: FAGERIA, N. K.; STONE, F. L.; SANTOS, B. A. (Eds.). Manejo da fertilidade do solo para arroz irrigado. Santo Antônio de Goiás: Embrapa Arroz e Feijão, 2003, cap. 1, p. 13-23.

FAGERIA, N. K.; SANTOS, A. B. Resposta do arroz irrigado à adubação verde e química no Estado de Tocantins. Revista Brasileira de Engenharia Agrícola e Ambiental, Campina Grande, v. 11, n. 4, p. 387-392, 2007.

FAGERIA, N. K.; SANTOS, A. B.; OLIVEIRA, J. 
P. Nitrogen-Use Efficiency in Lowland Rice Genotypes under Field Conditions. Communications in soil science and plant analysis, Philadelphia, v. 44, n. 17 , p. 2497-2506, 2013.

FAGERIA, N. K.; STONE, L. F. Manejo do nitrogênio. In: FAGERIA, N. K.; STONE, L. F.; SANTOS, A. B. (Eds.). Manejo da fertilidade do solo para o arroz irrigado. Santo Antônio de Goiás: Embrapa Arroz e Feijão, 2003, cap. 3, p. 51-94.

FRAGOSO, D. B. et al. Caracterização e diagnóstico da cadeia produtiva do arroz no Estado do Tocantins. 1. ed. Brasília, DF: Embrapa, 2013. $40 \mathrm{p}$

GUINDANI, R. H. P.; ANGHINONI, I.; NACHTIGALL, G. R. DRIS na avaliação do estado nutricional do arroz irrigado por inundação. Revista Brasileira de Ciência do Solo, Viçosa, v. 33, n. 1, p. 109-118, 2009.

KLUTHCOUSKI, J. et al. Manejo do solo e o rendimento de soja, milho, feijão e arroz em plantio direto. Scientia Agricola, Piracicaba, v. 57, n. 1, p. 97-104, 2000.

KUMAR, V.; LADHA, J. K. Direct seeding of rice: recent developments and future research needs. Advances in Agronomy, San Diego, v. 111, n. 1, p. 297-396, 2011.

MALAVOLTA, E. Elementos de nutrição mineral de plantas. 1. ed. São Paulo, SP: Agronômica Ceres, $1980.251 \mathrm{p}$.

MALAVOLTA, E.; VITTI, G. C.; OLIVEIRA, S. A. Avaliação do estado nutricional das plantas: princípios e aplicações. 2. ed. Piracicaba, SP: POTAFOS, 1997. 319 p.

MATTOS, M. L. T. Impacto ambiental. Disponível em: $\quad<$ https://www.agencia.cnptia.embrapa.br/ Repositorio/

IMPACTO+AMBIENTAL_000fx7s102v02wyiv80u 5vcsv015egze.pdf $>$. Acesso em: 10 set. 2014.

MARY, B. et al. Interactions between decomposition of plant residues and nitrogen cycling in soil. Plant and soil, Dordrecht, v. 181, n. 1, p. 71-82, 1996.

MCLAREN, R. G.; CAMERON, K. C. Soil science: sustainable production and environmental protection. 2. ed. Auckland: Oxford University Press, 1996. 304 p.

MONIZ, A. C.; JORGE, J. A.; VALADARES, J. M. A. S. Métodos de análise química, mineralógica e física de solos. 2. ed. Campinas, SP: Instituto
Agronômico de Campinas. 2009. 77 p.

NASCENTE, A. S. et al. Atributos químicos de latossolo sob plantio direto afetados pelo manejo do solo e rotação de culturas. Revista Caatinga, Mossoró, v. 27, n. 4, p. 153-163, 2014.

NASCENTE, A. S. et al. Cover crops can affect soil attributes and yield of upland rice. Australian Journal of Crop Science, Lismore, v. 10, n. 2, p. 176-184, 2016.

NASCENTE, A. S.; CRUSCIOL, C. A. C. Soil Aggregation, Organic Carbon Concentration, and Soil Bulk Density As Affected by Cover Crop Species in a No-Tillage System. Revista Brasileira de Ciência do Solo, Viçosa, v. 39, n. 3, p. 871-879, 2015

NASCENTE, A. S.; CRUSCIOL, C. A. C.; COBUCCI, T. The no-tillage system and cover crops - Alternatives to increase upland rice yields. European Journal of Agronomy, Amsterdam, v. 45, n. 1, p. 124-131, 2013.

PELÚZIO, J. M. et al. Comportamento de Cultivares de Soja Sob Condições de Várzea Irrigada no Sul do Estado do Tocantins Entressafra 2005. Bioscience Journal, Uberlândia, v. 24, n. 1, p. 75-80, 2008.

POUDEL, D. D.; HORWATH, W. R.; LANINI, W. T. Comparison of soil $\mathrm{N}$ availability and leaching potential, crop yields and weeds in organic, low-input and conventional farming systems in northern California. Agriculture Ecosystems and Environment, Amsterdam, v. 90, n. 2, p. 125-137, 2002 .

ROSECRANCE, R. C. et al. Denitrification and N mineralization from hairy vetch (Vicia villosa Roth) and rye (Secale cereale L.) cover crop monocultures and bicultures. Plant and Soil, Dordrecht, v. 227, n. $1-2$, p. $283-290,2000$

ROSOLEM, C. A.; CALONEGO, J. C.; FOLONI, J. S. S. Lixiviação de potássio da palha de coberturas de solo em função da quantidade de chuva recebida. Revista Brasileira de Ciência do Solo, Viçosa, v. 27 , n. 2 , p. $355-362,2003$.

SILVA, F. A. S.; AZEVEDO, C. A. V. Principal Components Analysis in the Software Assistat-Statistical Attendance. In: WORLD CONGRESS ON COMPUTERS IN AGRICULTURE, 7., 2009, Reno-NV-USA. Annals... Reno: American Society of Agricultural and Biological Engineers, 2009. p. 22-24.

SILVA, C. A.; VALE, F. R.; GUILHERME, L. R. G. Nitrificação em latossolos da região sul de Minas 
Gerais: efeito da acidez do solo. Ciência e Prática, Lavras, v. 18, n. 1, p. 388-394, 1994.

THONNISSEN, C. D. et al. Legume decomposition and nitrogen release when applied as green manures to tropical vegetable production systems. Agronomy Journal, Madison, v. 92, n. 2, p. 253-260. 2000.

VERNETTI JUNIOR, F. J.; GOMES, A. S. SCHUCH, L. O. B. Sucessão de culturas em solos de várzea implantadas nos sistemas plantio direto $\mathrm{e}$ convencional. Revista Braileira de Agrociênc, Pelotas, v. 15, n. 1-4, p. 37-42, 2009. 